\title{
Nutritional Composition of Selected Commercial Biscuits in Malaysia
}

(Komposisi Nutrien dalam Beberapa Biskut Komersial Terpilih di Malaysia)

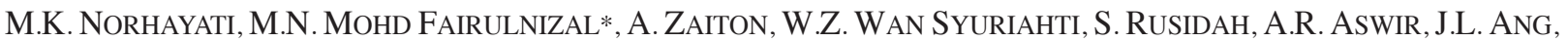 \\ M.N. MoHD NAEEM, M. SURAiAmi, J. MOHD AZERULAZREE \& B. VimALA
}

\begin{abstract}
The objective of this study was to determine the nutrient composition of selected commercial biscuits in Malaysia. A total of six brands from each type of biscuit (chocolate chip, corn, cracker with sugar, vegetable flavoured cracker, cream filled, oatmeal, shortbread and fully coated chocolate wafer) and five brands of wholemeal crackers were sampled from local supermarkets in the Klang Valley. The total energy content in commercial biscuits was ranging from 453.30 to $499.25 \mathrm{kcal} / 100 \mathrm{~g}$. Carbohydrate was the major macronutrient in commercial biscuits ranging from 56.86 to 66.07 $\mathrm{g} / 100 \mathrm{~g}$. The highest protein content was found in the wholemeal crackers $(9.92 \mathrm{~g} / 100 \mathrm{~g}$ ) and the lowest protein content was found in the cream filled biscuits $(5.65 \mathrm{~g} / 100 \mathrm{~g})$. Fat content lay in the range of 16.89 to $25.75 \mathrm{~g} / 100 \mathrm{~g}$. The major minerals detected in biscuits were sodium, followed by calcium and magnesium. The vitamin content in $A$ and $E$ of the biscuits examined was almost comparable. Small quantities of trans fatty acids were detected in all biscuits in the range of 0.02 to $0.68 \mathrm{~g} / 100 \mathrm{~g}$. These findings indicate that Malaysian commercial biscuits are a good source of carbohydrate (34.12-39.64 g per serving), calcium (26.09-384.67 g per serving), magnesium (10.42-37.24 g per serving) and contain low proportion of trans fatty acids (0.01-0.41 g per serving).
\end{abstract}

Keywords: Commercial biscuits; fatty acids; minerals; Malaysia; nutritional composition

\section{ABSTRAK}

Objektif kajian ini adalah untuk menentukan komposisi nutrien dalam beberapa biskut komersial terpilih di Malaysia. Sebanyak enam jenama daripada setiap jenis biskut (cip coklat, jagung, 'cracker' dengan gula, 'cracker' berperisa sayursayuran, diisi krim, 'oatmeal', 'shortbread' dan wafer coklat bersalut sepenuhnya) dan lima jenama biskut 'cracker' gandum tulen telah disampel dari pasar raya tempatan di Lembah Klang. Biskut komersial mengandungi jumlah tenaga dalam julat 453.30-499.25 kilokalori. Karbohidrat adalah makronutrien utama dalam biskut komersial yang berjulat daripada 56.86-66.07 g/100 g. Kandungan protein tertinggi terdapat dalam 'cracker' gandum tulen (9.92 g/100 g) dan kandungan protein yang paling rendah ditemui dalam biskut diisi krim (5.65 g/100 g). Kandungan lemak berada dalam lingkungan 16.89-25.75 g/100 g. Mineral utama dikesan dalam biskut adalah natrium, diikuti dengan kalsium dan magnesium. Kandungan vitamin A dan E dalam biskut yang dianalisis semuanya hampir sama. Kuantiti kecil asid lemak trans dikesan pada semua biskut ialah di dalam lingkungan (0.02-0.68 g/100 g). Penemuan ini menunjukkan bahawa biskut komersial di Malaysia adalah punca yang baik untuk karbohidrat (34.12-39.64 g per sajian), kalsium (26.09-384.67 g per sajian), magnesium (10.42-37.24 g per sajian) dan mengandungi perkadaran asid lemak trans yang rendah (0.01-0.41 g per sajian).

Kata kunci: Asid lemak trans; biskut komersial; komposisi makanan; Malaysia; mineral

\section{INTRODUCTION}

In Malaysia, there is an increasing trend in the consumption of ready-made or convenience foods such as bread, biscuits and cake. A study of food consumption patterns among Malaysian adults carried out between October 2002 and December 2003, placed biscuits in the top ten food items consumed daily by this group. The study also showed that $16.3 \%$ of the local population consumed an average of 5 pieces of biscuits daily (Norimah et al.2008), showing that biscuits were a popular food item in Malaysia. Biscuits are also the most popularly consumed bakery item in other parts of the world. The reasons for such wide popularity are their ready to eat nature, affordable cost, good nutritional quality, availability in different flavours and longer shelf life (Gandhi et al. 2001).

Working adults in Malaysia have a busy lifestyle, thus biscuits constitute a food that may be consumed anywhere and anytime without too much bother. This is one of the reasons biscuits are highly consumed by Malaysians in urban population. Nowadays, a heightened awareness has made Malaysian consumers demand healthier foods and biscuits are not immune to this trend. In response to this awareness and demands, biscuit manufacturers produce healthier biscuits such as cereal-based biscuits and vegetable-based biscuits. Despite this, Malaysian consumers still prefer normal flavoured biscuits such as 
chocolate chip and cream crackers. Crackers are biscuits that are unsweetened, salty, thin and crispy and cream crackers are highly sought by consumers in Malaysia chalking up a significant place in biscuit sales in the country (Neo et al. 2007).

In order to boost the sale of biscuits in the country, manufacturers in Malaysia introduced convenient individual biscuit packaging. This step also caters to the busy lifestyles of Malaysian consumers who need to consume crackers wherever they want. Biscuits are also a food item that is included in the Updates of Malaysian Food Composition Database. Commercial trade and market globalization dictates that each should need to have a comprehensive and current Food Composition Database to comply with the requirement for nutritional labelling. Furthermore, Food Composition Database facilitates the trade among various nations. The aim of this study was to determine the nutritional composition of six selected Malaysian commercial biscuits.

\section{MATERIALS AND METHODS}

\section{SAMPLE COLLECTION AND PREPARATION}

The criteria for biscuits selection was based on the data provided from Malaysian Adult Nutrition Survey carried out between October 2002 and December 2003. The most consumed biscuits, taken from both the $24 \mathrm{~h}$ diet recall and food frequency questionnaire methods, were selected for analysis. A total number of six brands from each types of biscuit, namely chocolate chip, corn, cracker with sugar, vegetable flavoured cracker, cream filled, oatmeal, shortbread, and fully coated chocolate wafer and five brands of wholemeal crackers were sampled from local supermarkets in the Klang Valley. For each brand, one kilogram of samples was purchased. All samples were collected in 2011. They were then ground into fine powder using a food grinder, transferred into the air tight containers and kept at ambient temperature until further analysis. Analyses were carried out in duplicate.

\section{PROXIMATE ANALYSIS}

The moisture content was determined using the drying method. Ten grams $(10 \mathrm{~g})$ of finely ground samples was dried for $5-8 \mathrm{~h}$ in air-oven at $105^{\circ} \mathrm{C}$ until constant weight was obtained. The amount of moisture in foods was the difference between the weight before and after drying (AOAC 2008).

Protein content was determined using Kjeldahl method (AOAC 2005). A finely ground sample (1 g) was digested with $15 \mathrm{~mL}$ concentrated sulphuric acid $(36 \mathrm{~N})$ at $420^{\circ} \mathrm{C}$ for $1 \frac{1}{2} \mathrm{~h}$ using a block digestor (Gerhardt, Germany). The digested solution was cooled at room temperature and then transferred into a distillation unit (Gerhardt, Germany) where the contents were diluted with $100 \mathrm{~mL}$ distilled water, followed by the addition of $80 \mathrm{~mL} 40 \%$ sodium hydroxide solution. The mixture was then distilled and the ammonia liberated was collected in a $400 \mathrm{~mL}$ beaker containing $50 \mathrm{~mL} 2 \%$ boric acid and a few drops of screened methyl red indicator solution. This distillate was then titrated against $0.1 \mathrm{~N} \mathrm{H}_{2} \mathrm{SO}_{4}$ and calculated for total nitrogen. A conversion factor of 6.25 was used to convert the measured nitrogen content to protein.

Fat content was determined by the semi continuous solvent extraction method (AOAC 2006). A finely ground and homogenised sample (1-3 g) was weighed into a hydrolysing capsule for hydrolysis using an automatic hydrolysing unit (Gerhardt, Germany). The hydrolysed sample was then transferred into an extraction thimble. Cotton was placed as a lid and the fat extracted with petroleum ether at $40-60^{\circ} \mathrm{C}$ using an automated fat extraction system (Gerhardt, Germany) for 2-3 h. The petroleum ether collected was dried at $105^{\circ} \mathrm{C}$ for $3 \mathrm{~h}$, then cooled in a desiccator for $1 \mathrm{~h}$ and weighed for the fat content. Available carbohydrate content was calculated by subtracting the sum of protein, fat, moisture, ash and total dietary fibre from $100 \%$ (Menezes et al. 2004).

Total dietary fibre (TDF) was determined using the enzymatic-gravimetric method (AOAC 2005). Samples of dried foods $(1 \mathrm{~g})$ with fat removed if containing $>10 \%$ fat, undergo sequential enzymatic digestion by heat stable $\mu$-amylase, protease and amyloglycosidase to remove starch and protein. For TDF, the enzyme digestate was treated with alcohol to precipitate soluble dietary fiber (SDF) and the TDF residue was filtered, washed with alcohol and acetone, dried and weighed. The TDF values were corrected for protein, ash and reagent blank $(\mathrm{TDF}=$ weight of residue - weight (protein + ash)).

Ash content was determined using the dry ashing method (AOAC 2005). A clean silica crucible was placed into a muffle furnace at $550^{\circ} \mathrm{C}$ over $5 \mathrm{~h}$. The silica crucible was cooled for $1 \mathrm{~h}$ in a desiccator and weighed at constant weight. Finely ground sample (3-5 g) was then weighed into the constant weight crucible. The sample was preashed by heating the crucible on a hot plate that was subsequently placed in the muffle furnace at $550^{\circ} \mathrm{C}$ for $6-8$ $\mathrm{h}$ to complete the ashing process. The crucible was then cooled for $1 \mathrm{~h}$ and weighed for ash content.

\section{MINERALS CONTENT}

Mineral content such as calcium $(\mathrm{Ca})$, sodium $(\mathrm{Na})$, magnesium $(\mathrm{Mg})$, iron $(\mathrm{Fe})$, zinc $(\mathrm{Zn})$ and copper $(\mathrm{Cu})$ were performed using Inductively Coupled Plasma Optical Emission Spectrometry (ICP-OES) (Perkin Elmer, USA). Approximately, $3 \mathrm{~g}$ of finely ground samples were digested using dry ashing method (AOAC 2005). The resulting ash was dissolved in $7 \mathrm{~mL}$ concentrated hydrochloric acid and then diluted to $100 \mathrm{~mL}$ with deionized water. The solution was filtered and the mineral content determined using ICPOES against the standard solution.

\section{VITAMINS ANALYSIS}

The analysis for the 5 types of vitamin B was carried out simultaneously using High Performance Liquid 
Chromatography with Diode Array and Fluorescence Detector. The method involved a simple removal of protein by chemical precipitation using trichloroacetic acid, followed by reversed phase LC with ion-pair reagent (Woollard \& Indyk 2002). Six grams of sample was weighed into a $100 \mathrm{~mL}$ flask. The sample was dissolved in $30 \mathrm{~mL}$ warm water followed by the addition of 0.6 M trichloroacetic acid (TCA). The flask containing the mixture was shaken on a mechanical shaker for $15 \mathrm{~min}$. The resulting mixture was filtered into an HPLC vial and B1, B3 and B9 content determined by the Diode Array Detector against a standard solution, while the contents for B2 and B6 were determined by Flourescence Detector against the standard solution.

The analysis for Vitamin C was carried out using High Performance Liquid Chromatography (HPLC) with Diode Array Detector. The method involved dissolution of sample in Tris (2-carboxyethyl)-phosphine hydrochloride acid and simple removal of protein using trichloroacetic acid (TCA) followed by reversed phase LC (Brause et al. 2003). Five grams of sample was weighed into a 100 $\mathrm{mL}$ flask and then dissolved and acidified in $20 \mathrm{~mL}$ Tris (2-carboxyethyl)-phosphine hydrochloride solution. This solution was then made up to $100 \mathrm{~mL}$ with $1 \%$ TCA solution and shaken for about $1 \mathrm{~min}$. The resulting mixture was filtered into an HPLC vial and Vitamin C content determined by Diode Array Detector against the standard solution.

The analysis for fat soluble vitamins A and E, was carried out simultaneously using High Performance Liquid Chromatography with Diode Array and Fluorescence Detector. This method involved the saponification of standards and samples in basic ethanol-water solution, extraction of the analyte from the neutralised mixture, followed by reversed phase LC (DeVries \& Silvera 2002). During this process, fat was converted into fatty acids and vitamin $\mathrm{A}$ and vitamin $\mathrm{E}$ into retinol and alphatocopherol, respectively. A $5 \mathrm{~g}$ sample was weighed into a $250 \mathrm{~mL}$ flask followed by the addition of a pea-sized pyrogallol acid as an antioxidant and $40 \mathrm{~mL}$ of $95 \%$ ethanol. This solution was then saponified with $10 \mathrm{~mL}$ of $50 \%$ potassium hydroxide $(\mathrm{KOH})$ under controlled conditions. Ten $\mathrm{mL}$ of glacial acetic acid was then added to neutralise the $\mathrm{KOH}$ and the vitamin $\mathrm{A}$ and vitamin $\mathrm{E}$ extracted into a mixture of THF and ethanol $(50+50)$ solution. The extractant was filtered into an HPLC vial and the Vitamin A content was determined by Diode Array Detector against the standard solution, while Vitamin E content was determined by Fluorescence Detector against the standard solution.

\section{TOTAL SUGAR CONTENT}

The analysis of total sugars, sucrose, glucose, fructose, lactose and maltose were done using High Performance Liquid Chromatography (HPLC) with Evaporative Light Scattering Detector (ELSD).

\section{FATTY ACID PROFILE}

Fatty acids in samples were determined by converting the triglycerides and phospholipids in the samples into fatty acids methyl esters (FAME) by saponification and esterification in the presence of boron trifluoride with triglyceride triundecanoin $\mathrm{C}_{11: 0}$ added as the internal standard (AOAC 2005). The resulting fatty acid methyl esters were then analysed using Agilent Technologies 7890A Gas Chromatograph with a Flame Ionisation Detector, equipped with a capillary column DB-WAX (30 $\mathrm{m} \times 0.250 \mathrm{~mm}$, film thickness $0.25 \mathrm{um}$ ) and helium as the carrier gas. Individual fatty acid concentrations in the samples were determined by comparing their respective chromatograms with that of the standard. Total fat is calculated as sum of the individual fatty acid expressed as triglyceride equivalents, while saturated, monounsaturated, polyunsaturated and trans fats were calculated as sum of the respective fatty acids.

\section{CHOLESTEROL ANALYSIS}

Lipid in the test portion of a sample was saponified with ethanolic $\mathrm{KOH}$ solution. The unsaponified fraction containing cholesterol and other sterols was extracted with toluene and derivatised with hexamethyldisilane (HMDS) and trimethylchlorosilane (TMCS) to its trimethylsilyl (TMS) ethers which were then quantified by gas chromatography (AOAC 2008). A $5 \mathrm{~g}$ sample was weighed into a $250 \mathrm{~mL}$ flask followed by the addition of $40 \mathrm{~mL}$ of $95 \%$ ethanol. This solution was then saponified with $8 \mathrm{~mL}$ of $50 \%$ potassium hydroxide $(\mathrm{KOH})$ under controlled condition. Once completed, the mixture was extracted with toluene to remove the unsaponified fraction containing cholesterol and other sterols. The toluene extract was then washed with water and the toluene collected was then evaporated to dryness. The residue left was then dissolved in dimethylformamide (DMF) solution and derivatized with HMDS and TMS and subsequently analysed for sterols using 5 alpha cholestane as the internal standard.

\section{STATISTICAL ANALYSIS}

SPSS (V 18.0) was used for the statistical analyses of this study. The mean difference among groups was compared using Kruskal-Wallis test. Significance was accepted at probability $p<0.05$. All results were reported as mean and range.

\section{RESULTS AND DISCUSSION}

\section{PROXIMATE COMPOSITION}

Table 1 shows the proximate composition of commercial biscuits in Malaysia. Carbohydrate was the major macronutrient in commercial biscuits and ranged from 56.86 to $66.07 \mathrm{~g} / 100 \mathrm{~g}$. Each serving consists of 6 pieces and each piece weighs about $10 \mathrm{~g}$ on average. One serving of these biscuits contains 34.12 to $39.64 \mathrm{~g}$ of total 


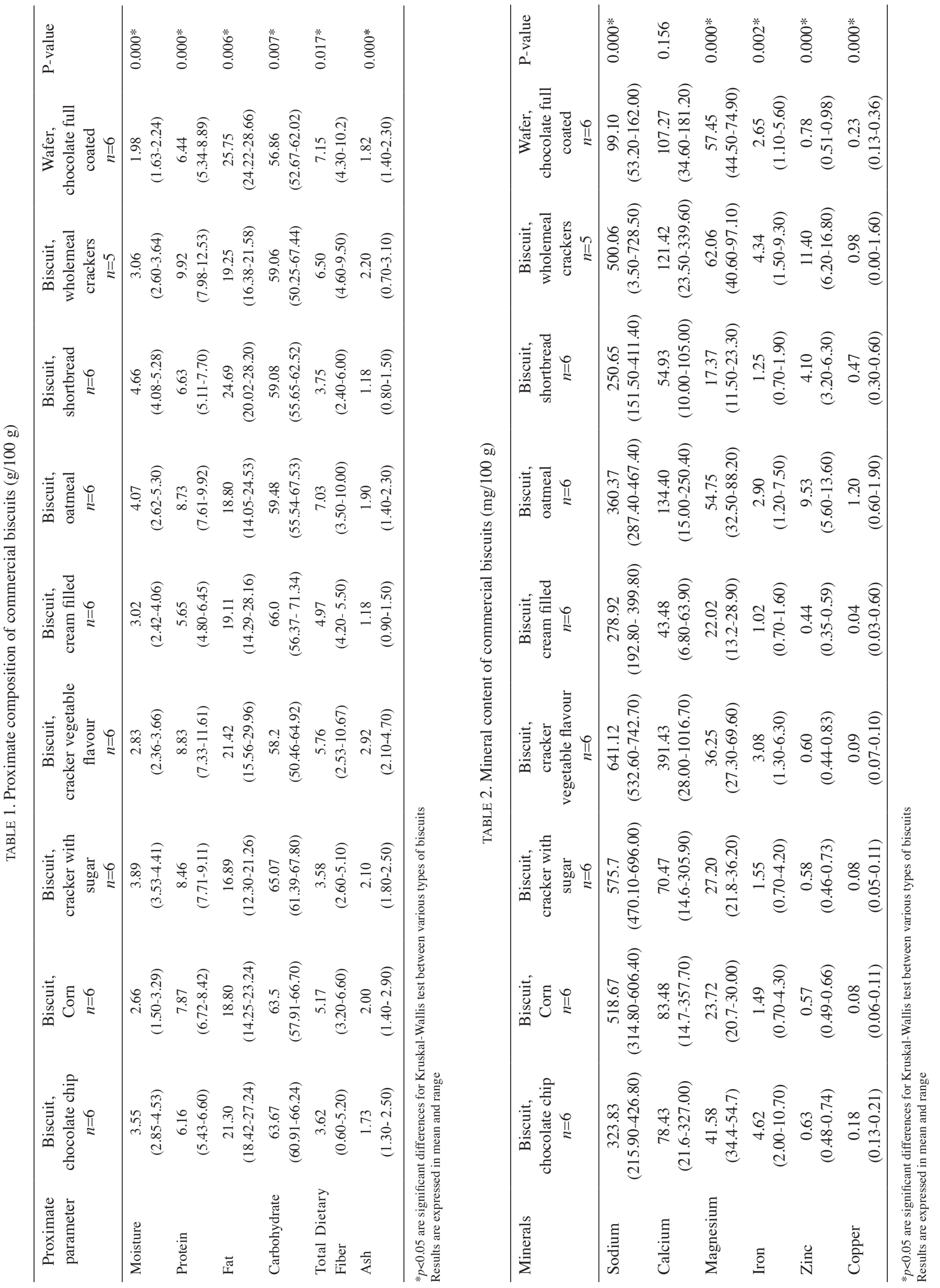


carbohydrate and it contributes 136.48 to $158.56 \mathrm{kcal}$ of total calories. Fat content was ranged from 16.89 to 25.75 $\mathrm{g} / 100 \mathrm{~g}$. Among these biscuits, fully coated chocolate wafer contributed the highest calorie per serving (139.05 kcal) compared to cracker with sugar $(91.17 \mathrm{kcal})$. Both carbohydrate and fat content shows significant different $(p<0.05)$ between different types of biscuits. While the protein content varied among all the biscuits with high protein content measured in oatmeal biscuits $(8.73 \mathrm{~g} / 100$ $\mathrm{g}$ ), cracker vegetable flavour biscuit $8.83 \mathrm{~g} / 100 \mathrm{~g}$ and wholemeal crackers biscuit $9.92 \mathrm{~g} / 100 \mathrm{~g}$. One serving of oatmeal, cracker vegetable flavour and wholemeal crackers contain $5.24,5.30$ and $5.95 \mathrm{~g}$ of protein, respectively. High protein content is measured when whole grain is the major ingredient. Whole grain foods are rich in a number of vitamins, minerals, dietary fibre, protein and phytochemical (Fardet 2010; Marquart et al. 2002). The moisture content was ranged from 1.98 to $4.67 \mathrm{~g} / 100 \mathrm{~g}$ and shows a variation among all the biscuits. Moisture plays a critical role in determining the quality and shelf life of sugar-based confections (Ergun et al. 2010). The ash content also differs among all the biscuit. The ash content of a food sample related to the mineral elements present in the food sample (Ogu \& Ugwu 2011).

Meanwhile, the total dietary fibre in all the samples ranged from 3.58 to $7.15 \mathrm{~g} / 100 \mathrm{~g}$. Fully coated chocolate wafer, oatmeal biscuit and wholemeal crackers contain the highest dietary fibre in one serving $(4.29,4.22$ and 3.92 , respectively). There was an effort by the industry to increase the total dietary fibre intake of populations by using oat and wholemeal grain as ingredient in the biscuits. Oat and wholegrain foods are rich in dietary fibre (Fardet 2010; Marquart et al. 2002). There were also available reports on the use of oat bran, wheat bran, rice bran as a source of dietary fibre content in bread and other bakery products (Laurikainen et al. 1998; Sidhu et al. 1999).

\section{MINERALS COMPOSITION}

The mineral composition of commercial biscuits in Malaysia is shown in Table 2. The major minerals detected in biscuits were sodium (Na) 99.10 to $641.12 \mathrm{mg} / 100 \mathrm{~g}$, calcium (Ca) 43.48 to $134.40 \mathrm{mg} / 100 \mathrm{~g}$ and magnesium $(\mathrm{Mg}) 17.37$ to $62.06 \mathrm{mg} / 100 \mathrm{~g}$. Both $\mathrm{Na}$ and $\mathrm{Mg}$ show significant difference $(p<0.05)$ between different types of biscuits. Meanwhile, there were no significant difference $(p>0.05)$ in the $\mathrm{Ca}$ content in all the biscuits studied. The iron $(\mathrm{Fe})$ content in all types of biscuits ranges from $1.25 \mathrm{mg} / 100 \mathrm{~g}$ to $4.62 \mathrm{mg} / 100 \mathrm{~g}$. There was significant difference $(p<0.05)$ in the Fe content among various types of biscuits. The iron content in chocolate chip biscuits 4.62 $\mathrm{mg} / 100 \mathrm{~g}$ in this study is higher compared to data from USDA Nutrient Database (USDA SR25 2012) $2.7 \mathrm{mg} / 100$ g, Australia Nutrient Database (NUTTAB 2010) $1.9 \mathrm{mg} / 100$ $\mathrm{g}$ and UK Nutrient Database (CoF IDS 2002) $1.3 \mathrm{mg} / 100$ g. Zinc $(\mathrm{Zn})$ and copper $(\mathrm{Cu})$ were also detected but in small amounts.

\section{VITAMINS CONTENT}

Table 3 shows the vitamins content of commercial biscuits in Malaysia. There are significant difference $(p<0.05)$ in vitamin B1, vitamin B2, vitamin B6 and B9 between different types of biscuits. Meanwhile, there were no significant differences in vitamin B3 in all the biscuits studied. No vitamin $\mathrm{C}$ was detected in all the various biscuits studied. Vitamin A content ranges from 35.00 to $143.00 \mu \mathrm{g} / 100 \mathrm{~g}$ while vitamin E content ranges from 0.23 to $6.33 \mathrm{mg} / 100 \mathrm{~g}$. No significant differences $(p>0.05)$ in vitamin A and E content were detected in all the samples. Vitamin A is important for vision and healthy skin whereas vitamin $\mathrm{E}$ acts as an antioxidant and protects cell wall (Mahan \& Escott-Stump 2000). FAO/WHO (2002) recommends a vitamin A intake of $600 \mu \mathrm{g} R E /$ day for men aged 19 to 65 years old and $500 \mu \mathrm{g}$ RE/day for women aged 19 to 65 years old.

\section{SUGAR COMPOSITION}

The sugar content of Malaysian commercial biscuits is shown in Table 4. Results show that there are significant differences $(p<0.05)$ in the total sugar, sucrose, fructose, lactose and maltose content between different types of biscuits. While for glucose content, no significant differences $(p>0.05)$ shown. Sucrose which was detected in all types of biscuits was the major contributing sugar to the total sugar content. Sugar composition of commercial biscuits in Malaysia ranged from 4.96 to $39.13 \mathrm{~g} / 100 \mathrm{~g}$. The recommended intake of free sugars (monosaccharides and disaccharides added to food and naturally occurring sugars such as honey, syrups and fruit juices) by WHO/FAO (2003) that it should be less than $10 \%$ from total energy intake, for instance $50 \mathrm{~g}$ sugars for a $2000 \mathrm{kcal}$ diet.

\section{FATTY ACID COMPOSITION}

Fatty acid composition of Malaysian commercial biscuits is presented in Table 5. Saturated fatty acids (SFA) were the major fatty acids composition in all biscuits analysed and ranged from 8.99 to $16.28 \mathrm{~g} / 100 \mathrm{~g}$. The total SFA content showed a significant differences $(p<0.05)$ between different types of biscuits. Palmitic acid (C16:0) constituted the main component of the SFA, ranging from 7.39 to $9.07 \mathrm{~g} / 100 \mathrm{~g}$. The presence of high amounts of C16:0 indicates the use of palm oil and palm kernel oils as other sources of fat (Norhayati et al. 2011). This is reflected in the nutrition information on the packaging for most samples.

Total monounsaturated fatty acids (MUFA) ranged from 6.01 to $7.94 \mathrm{~g} / 100 \mathrm{~g}$. Total MUFA composition for all biscuits analysed were not significantly different $(p>0.05)$. Among the MUFA, oleic acid (C18:1) constituted the highest component with content ranging from 5.95 to $7.84 \mathrm{~g} / 100 \mathrm{~g}$.

There are significant differences $(p<0.05)$ in the total polyunsaturated fatty acids (PUFA) content between different types of biscuits. Among the PUFA, linoleic acid (C18:2) was the highest component with content ranging from 0.34 to $2.75 \mathrm{~g} / 100 \mathrm{~g}$ followed by eicosadienoic 


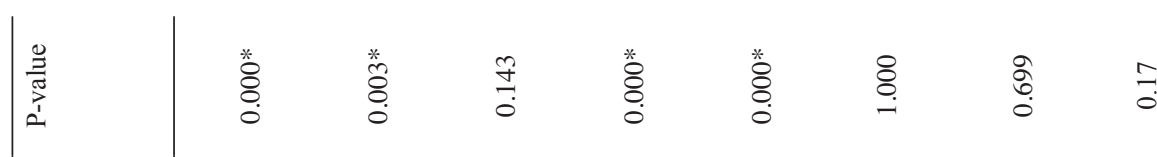

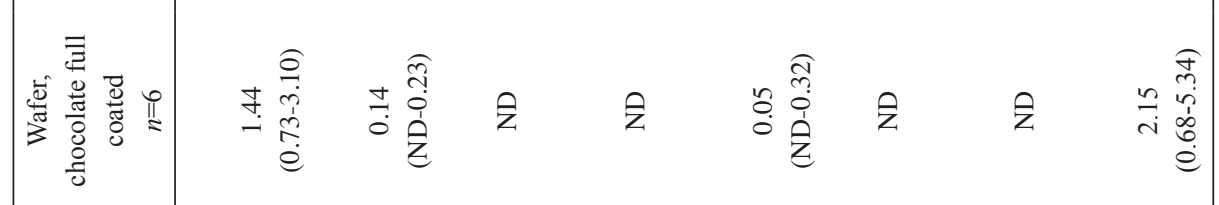

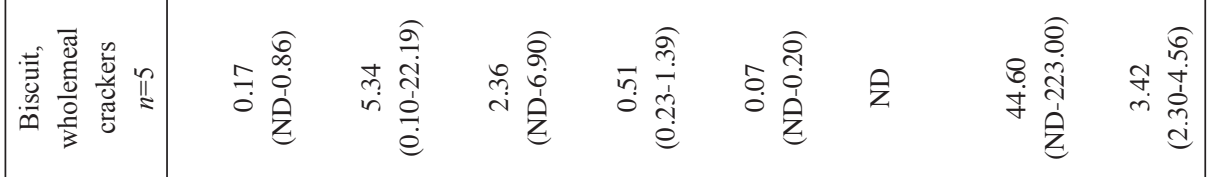

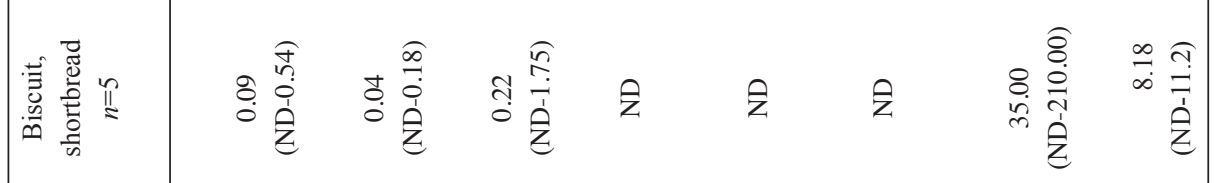

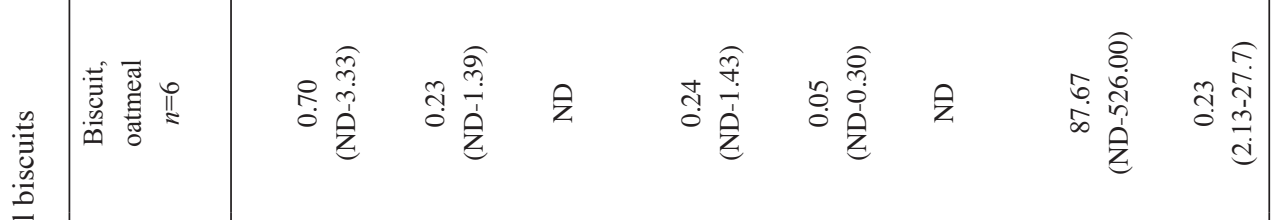

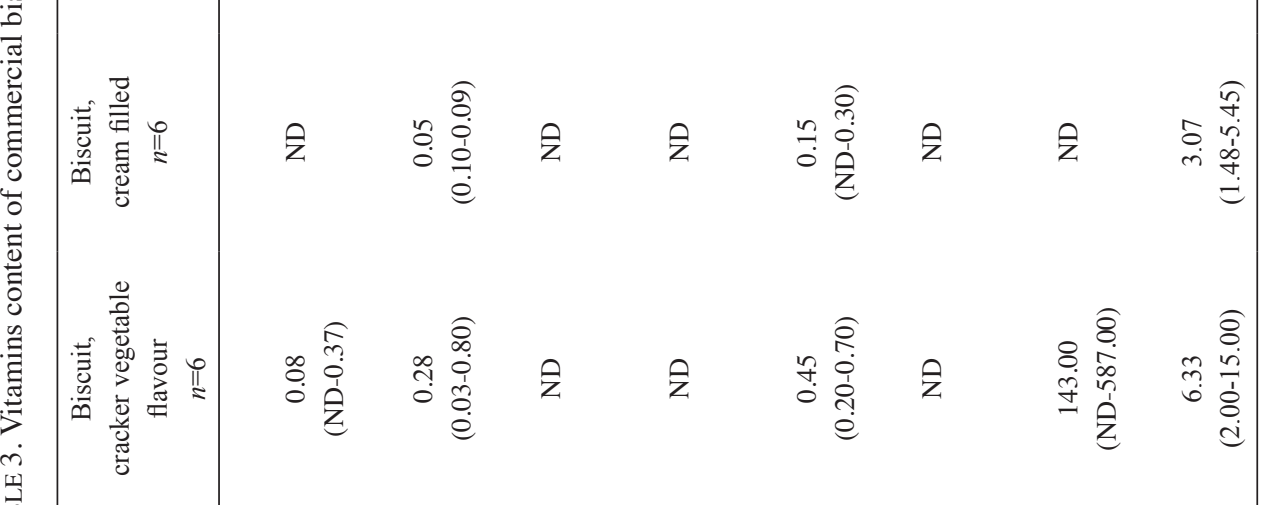

蓄

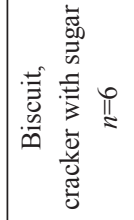

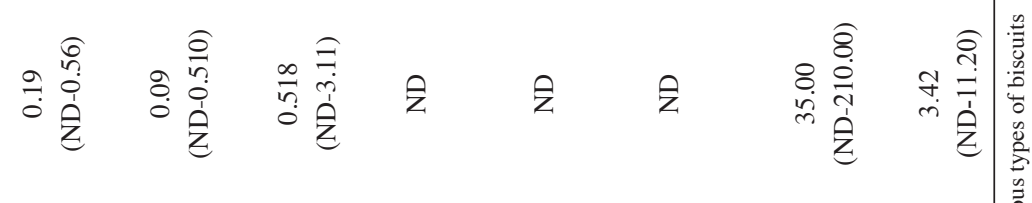

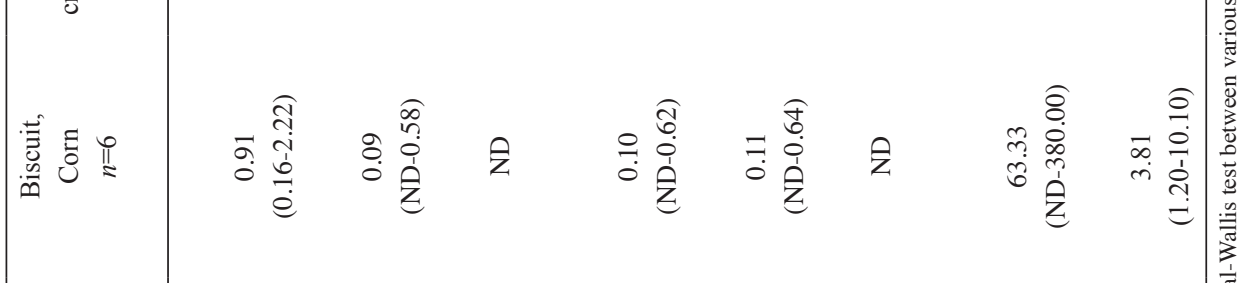

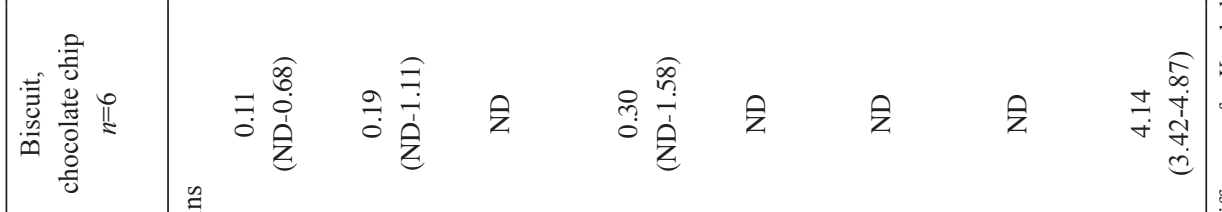

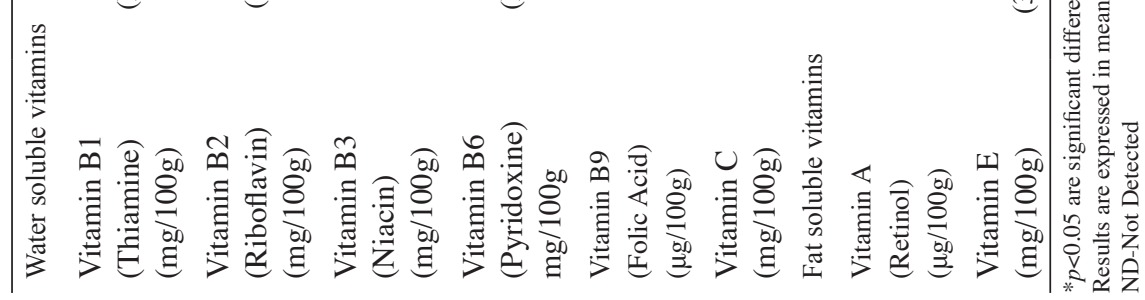




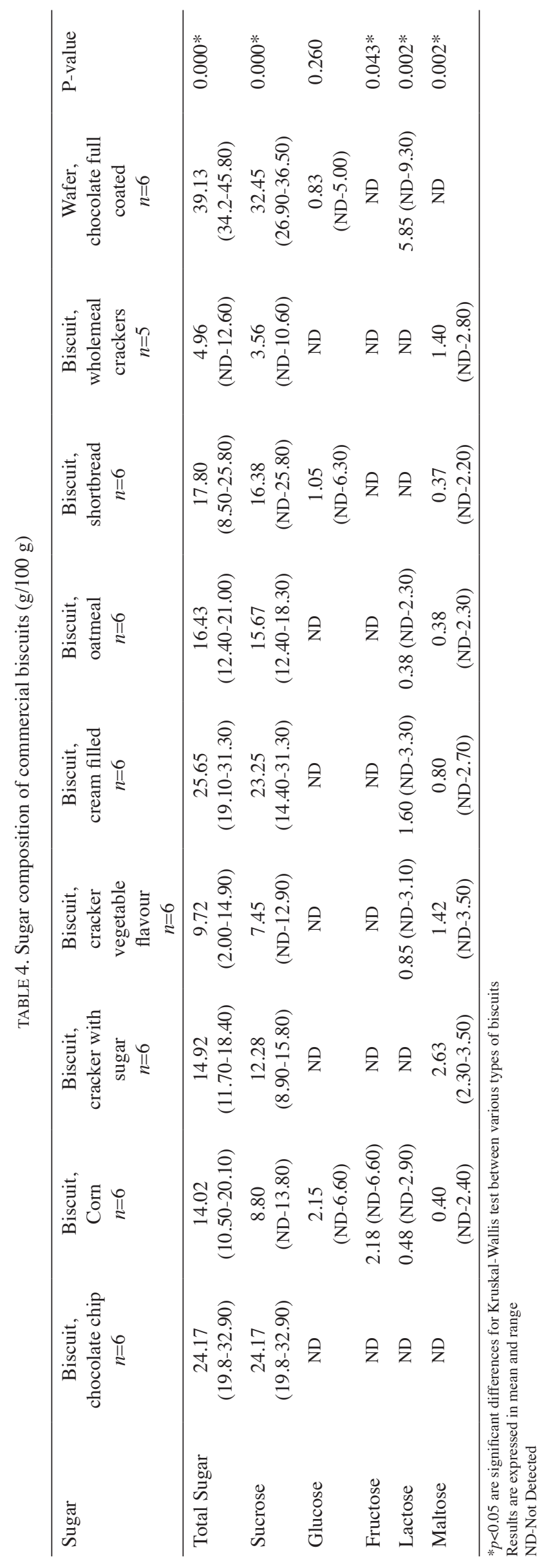




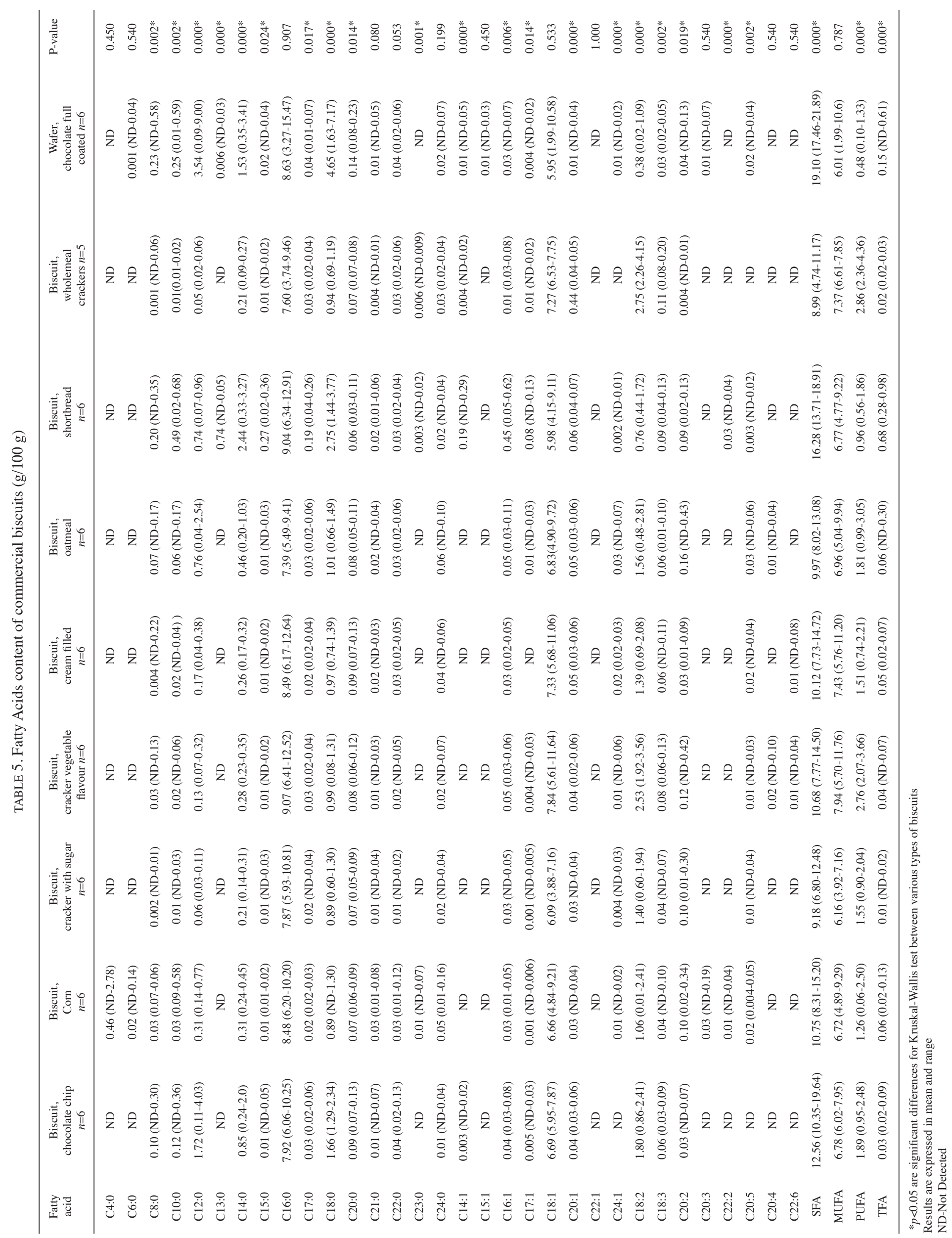




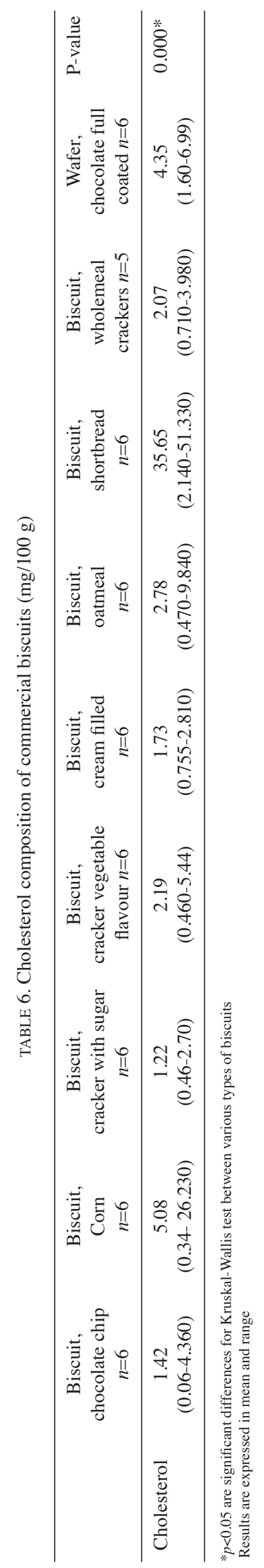


acid (C20:2), ranging from 0.004 to $0.16 \mathrm{~g} / 100 \mathrm{~g}$. Polyunsaturated fatty acids (PUFA) content were relatively low in this study ranging from 0.48 to $2.86 \mathrm{~g} / 100 \mathrm{~g}$. The low PUFA content indicates the use of concrete fats, often obtained by hydrogenation of refined vegetable oil (Caponio et al. 2006).

The trans fatty acid (TFA) content ranged from 0.02 to $0.68 \mathrm{~g} / 100 \mathrm{~g}$. There are significant differences $(p<0.05)$ in the TFA content between different types of biscuits. The trans fatty acid (TFA) content in Malaysian commercial biscuits was also very low ranging from 0.02 to $0.68 \mathrm{~g} / 100$ g. The WHO/FAO (2003) had recommended less than $1 \%$ of daily energy intake of TFAs. The TFA content among all types of biscuit is varied because of the differences in the conditions of the hydrogenation process, such as temperature, pressure, type and amount of catalyst and agitation rate which affect the resulting TFA content of the oil used. Food producers may use single hydrogenated and non-hydrogenated fats and oils to achieve a final product with the desirable characteristics (Innis et al. 1999; Karabut et al.2003). The TFA content of chocolate chip biscuits 0.03 $\mathrm{g} / 100 \mathrm{~g}$ in this study is lower than that in the data from UK Nutrient Database (CoF IDS 2002) which was $0.28 \mathrm{~g} / 100 \mathrm{~g}$. For cream filled biscuit, the result in this study $0.05 \mathrm{~g} / 100$ $\mathrm{g}$ is lower than that in the data from UK Nutrient Database (CoF IDS 2002) which was $2.0 \mathrm{~g} / 100 \mathrm{~g}$.

\section{CHOLESTEROL CONTENT}

The cholesterol content in Malaysian commercial biscuits is shown in Table 6. The cholesterol content in Malaysian commercial biscuit ranged from 1.42 to $35.65 \mathrm{mg} / 100 \mathrm{~g}$. There are significant differences $(p<0.05)$ in the cholesterol content between different types of biscuits. The WHO/FAO (2003) recommended nutrient intake of cholesterol should be less than $300 \mathrm{mg}$ per day.

\section{CONCLUSION}

This study showed that Malaysian commercial biscuits are a good source of carbohydrate, calcium and magnesium which benefit human health. It also shows that Malaysian biscuits contain low proportion of trans fatty acids compared to biscuits from other countries. These findings provide information on the nutritional content of various commercial biscuit products in Malaysia to assist the public in making healthy food choices. It also enhances the Malaysian Food Composition Database that is as reference by nutritionists, dieticians and researchers.

\section{ACKNOWLEDGEMENTS}

The authors thank the Director General of Health Malaysia and the Director of Institute for Medical research (IMR) for permission to publish this article. We also thank the Director General of Chemistry Department, the staff of the Nutrition Unit, Institute for Medical Research and the staff of the Food Section, Chemistry Department for their support in this study. This project was funded by a grant from the National Institute of Health/Institute for Medical Research, JPP-11-018.

\section{REFERENCES}

AOAC. 2008. Official Methods of Analysis of AOAC International. 18 th ed. current through $2^{\text {nd }}$ revision.). Maryland: Association of Official Analytical Chemists.

AOAC. 2006. Official Methods of Analysis of AOAC International. 18th ed. Revision 1. Maryland: Association of Official Analytical Chemists.

AOAC. 2005. Official Methods of Analysis of AOAC International. 18th ed. Maryland: Association of Official Analytical Chemists.

Brause, A.R., Woollard, D.C. \& Indyk, H.E. 2003. Determination of total vitamin $\mathrm{c}$ in fruit juices and related products by liquid chromatography: Interlaboratory Study. J. AOAC Int. 86(2): 367-374.

Caponio, F., Summo, C., Delcuratolo, D. \& Pasqualone, A. 2006. Quality of the lipid fraction of italian biscuits. J. Sci. Food Agr. 86: 356-361.

DeVries, J.W. \& Silvera, K.R. 2002. Determination of vitamins A (Retinol) and E (alpha-Tocopherol) in foods by liquid chromatography: Collaborative study. J. AOAC Int. 85(2): 424-434.

Ergun, R., Lietha, R. \& Hartel. R.W. 2010. Moisture and shelf life in sugar confections. Crit. Rev. Food Sci. Nutr. 50(2): 162-192.

Fardet, A. 2010. New hypotheses for the health-protective mechanisms of whole-grain cereals: What is beyond fibre? Nutr. Res. Rev. 23: 65-134.

Food Standard Agency. 2002. McCance and Widdowson's the composition of foods integrated dataset (CoF IDS).

http://www.food.gov.uk/science/dietarysurveys/dietsurveys/. Accessed on 9 November 2010.

Food Standard Australia New Zealand NUTTAB. 2010. http://www.foodstandards.gov.au/consumerinformation/ nuttab2010/nuttab2010onlineseAccessed on 9 November 2012.

Innis, S.M., Green, T.J. \& Halsey. T.K. 1999. Variability in the trans fatty acid content of foods within a food category: Implications for estimation of dietary trans fatty acids intakes. J. Am. Coll. Nutr. 18: 255-260.

Karabut, I., Kayahan, M. \& Yaprak, S. 2003. Determination of changes in some physical and chemical properties of soybean oil during hydrogenation. Food Chem. 81: 453-456.

Laurikainen, T., Harkonen, H., Autio, K. \& Poutanen, K. 1998. Effects of enzymes in fiber-enriched baking. J. Sci. Food Agr. 76: 239-249.

Mahan, L.K. \& Escott-Stump, S. 2000. Krause, Food, Nutrition \& Diet Theraphy. 10th ed. USA: W.B. Saunders Company.

Marquart, L., Slavin, J.L. \& Fulcher, R.G. 2002. Whole-Grain Foods in Health and Disease. St. Paul, Minnesota: American Association of Cereal Chemist Insc.

Menezes, E.W., De Melo, A.T., Lima, G.H. \& Lajolo, F.M. 2004. Measurement of carbohydrate components and their impact on energy value of foods. J. Food Compos. Anal. 17: 331-338.

Neo, Y.P., Tan, C.H. \& Ariffin, A. 2007. Fatty acid composition of five Malaysian biscuits (Cream Crackers) with special reference to trans- fatty acids. ASEAN Food. J. 14(3): $197-$ 204. 
Norhayati, M., Azrina, A., Norhaizan, M.E. \& Muhammad Rizal, R. 2011. Trans fatty acids content of biscuits commercially available in Malaysian market and comparison with other countries. Int. Food Res. J. 18(3): 1097-1103.

Norimah,A.K., Safiah, M., Jamal, K., Siti Haslinda, Zuhaida, H., Rohida, S., Fatimah, S., Siti Norazlin, Poh, B.K., Kandiah, M7, Zalilah, M.S., Wan Manan, W.M., Fatimah, S. \& Azmi, M.Y. 2008. Food consumption patterns: Findings from the Malaysian adult nutrition survey (MANS). Mal. J. Nutr. 14(1): 25-39.

Ogu, A.O. \& Ugwu, S.I. 2011. The proximate and mineral compositions of five major rice varieties in Abakaliki, SouthEastern Nigeria.Int.J. of Plant Physiol.Biochem. 3(2): 25-27.

Gandhi, A.P., Kotawaliwale, N., Kawalkar, J., Srivasta, D.C., Parihar, V.S. \& Raghu Nadh, P. 2001. Effect of incorporation of defatted soy flour on the quality of sweet biscuits. J Food Sci.Technol. 38: 502-503.

Sidhu, J.S., Suad, N. \& Al-Saquer, J.M. 1999. Effects of adding wheat bran and germ fractions on the chemical composition of high fiber toast bread. Food Chem. 67: 365-371.

U.S. Department of Agriculture, Agricultural Research Service (2012). USDA Nutrient Database for Standard Reference, Release 25. http://www.nal.usda.gov/fnic/foodcomp/search/. Accessed on 21 November 2012.

WHO. 2003. Diet, nutrition and the prevention of chronic diseases. Report of a Joint WHO/FAO/Expert Consultation. WHO Technical report Series 916. World Health Organization, Geneva.

Woollard, D.C. \& Indyk, H.E. 2002. Rapid determination of Thiamine, Riboflavin, Pyridoxine, and Niacinamide in infant formulas by liquid chromatography. J. AOAC Int. 85(4): 945-951.
FAO/WHO. 2002. Vitamin A. In Human Vitamin and Mineral Requirements. Report of a joint FAO/WHO Expert Consultation. FAO, Rome. pp 87-107.

M.K. Norhayati, M.N. Mohd Fairulnizal*, A.R. Aswir, J.L. Ang, M.N. Mohd Naeem, M. Suraiami,

J. Mohd Azerulazree \& B. Vimala

Institute for Medical Research, Jalan Pahang 50588 Kuala Lumpur

Malaysia

A. Zaiton \& W.Z. Wan Syuriahti

Chemistry Department, Jalan Sultan

46661 Petaling Jaya, Selangor Darul Ehsan

Malaysia

S. Rusidah

Nutrition Division, Ministry of Health

Aras 1, Blok E3, Parcel E

Pusat Pentadbiran Kerajaan Persekutuan 62590 Putrajaya

Malaysia

*Corresponding author; email: fairul@imr.gov.my

Received: 28 March 2014

Accepted: 20 October 2014 